\title{
Tolerance to iron chlorosis in non-grafted quince seedlings and in pear grafted onto quince plants
}

\author{
R.M. Prado ${ }^{1, *}$ and E. Alcantara-Vara ${ }^{2}$ \\ ${ }^{1}$ Department of Soils and Fertilizers, São Paulo State University, Via de Acesso Paulo Donato Castallane, s/ $n$. \\ 14884-900, Jaboticabal, Brazil. ${ }^{2}$ University of Córdoba, Avd. Medina Azahara, 5, 14071, Córdoba, Spain. \\ *Corresponding author: rmprado@fcav.unesp.br
}

\begin{abstract}
Grafting is a technique that may affect plant tolerance to iron chlorosis in plants cultivated for their fruit. Therefore, the objective of this study was to evaluate the tolerance of non-grafted quince seedlings and pear grafted onto quince plants cultivated in pots with alkaline soil. The experiment was conducted in a greenhouse at the University of Cordoba, Spain, in pots (3 L) filled with alkaline soil, with one plant per pot. The treatments consisted of two genotypes, quince (Cydonia oblonga Mill) semi-woody rooted cuttings, cultivar BA29, and pear (Pyrus Communis L.), cultivar Ercolini, grafted onto quince cultivar BA29 (rootstock), and two nutrient solutions with and without iron ( $80 \mu \mathrm{M} \mathrm{Fe-EDDHA)} \mathrm{arranged} \mathrm{in} \mathrm{a} \mathrm{completely} \mathrm{random} \mathrm{design}$ with eight repetitions. Each pot received $250 \mathrm{~mL}$ of the nutrient solution on June $3^{\text {rd }}$, 2010. Chlorophyll indirect measurements and the main stem length were evaluated for six weeks after the commencement of the treatments. During the last week, the main stem dry matter weight and the leaf total iron content were determined. It was found that grafting pear seedlings onto quince rootstock resulted in a higher tolerance to iron deficiency than when quince was not grafted. Non-grafted quince plants without iron in the nutrient solution, compared to the results with its application, showed low SPAD (Soil-Plant Analyses Development) values and resulted in plants with a lower leaf iron content and lower dry matter production; however, decreased seedling stem growth was observed only in the last week of cultivation.
\end{abstract}

Keywords: Cydonia oblonga, $\mathrm{pH}$, mineral nutrition, micronutrient. 


\section{Introduction}

Iron was the first element to be considered a micronutrient in plants; it is a component of clayish materials and, under some circumstances, is found to occur in levels insufficient to meet the needs of plants (Prado, 2008).

Alkaline soils are regarded as potential inducers of iron deficiency in plants even though the element might occur in high concentrations in the soil. The reason for this is that most of the iron is absorbed by soil particles in an insoluble form, which the plants are not capable of utilising, and the soluble portion is usually insufficient (Lindsay, 1995).

Alkalinity in soils may be due to the material from which the soil was formed having a high concentration of bicarbonate (Mengel et al., 1984) or to inadequacies in cultural practices, such as an excess of lime application when correcting for soil acidity. Iron deficiency may be aggravated by other factors, including soil flooding, compaction, high temperatures, and heavy fruit loads (Chaney, 1984). Iron in interaction with other nutrients may become scarcely available to the plant and also lead to nutritional disorders (Prado, 2008).

In some regions of the world, iron deficiency symptoms have been observed in plants under controlled environment agriculture (CEA) conditions due to a low iron content in nutrient solutions as a consequence of the use of non-chelated iron sources or, occasionally, to the inadequate control of the $\mathrm{pH}$ of the nutrient solution. In Brazil, iron deficiency has been reported in Oxisols of acid reaction and may be related to periods of drought, a condition in which iron diffusion in the soils is hampered mainly when lime followed by high doses of phosphorous fertilisers are applied to the soil (Nunes et al., 2004). This problem has been reported to occur in the Mediterranean area, mainly in Europe (Lindsay, 1995).
Among European countries, iron deficiency seems to reach the highest levels in Spain, with deficiency being reported to occur in an area of 284,000 hectares involving several crops (MAPA, 2007). The damaging effects of iron deficiency have been extensively described in the literature, mainly in fruit plants (Herrero and Abadia Conte, 1962), such as olive (Fernandez-Escobar et al., 1993), quince, pear (Tagliavini et al., 1995), lime (El-Kassas, 1984), peach (Sanz et al., 1997a), and kiwi (Tagliavini et al., 1995).

In addition to causing reductions in plant yield, iron deficiency may reduce fruit size and delay fruit maturation (Sanz et al., 1997b) and also reduce the intake of this element by humans. It is known that malnutrition is a serious cause of death worldwide each year, and it mainly results from the ingestion of food poor in micronutrients, especially iron (Stein, 2010). Thus, enriching human food with iron may save many lives.

Therefore, applying iron to plants, either via soil or foliar fertilisation, is important to reduce yield losses and also to improve the nutritional value of the fruit. The application of iron directly to the soil is a very expensive technique: according to data published by Tagliavini et al. (2000), this practice may represent up to $60 \%$ of the total of fertilisation costs. Similarly, the foliar application of fertilisers has some important drawbacks, such as a low residual effect, a small influence on plant growth between harvests, and a low mobility in the plant tissues, thus demanding frequent applications during the plant cycle.

An economically interesting way to reduce iron chlorosis problems in plants could be the use of genetically tolerant cultivars with a very high capability of absorbing iron from the environment, thus providing the plant with sufficient levels of iron. Alcantara (2005) observed differences in the tolerance to iron deficiency among different olive genotypes. This 
same behaviour was observed in oats (McDaniel and Brown, 1982), chickpea (Saxena and Sheldrake, 1980), beans (Zaitner et al., 1982), peanuts (Samdur et al., 2000), and pear (Ma et al., 2005). Studies concerning the genetic variability of quince genotypes to iron deficiency are scarce, whereas quite a few studies have been conducted in pear (Dolcet-Sanjuan et al., 1992; Cinelli et al., 1992).

The cultivation of fruit trees usually demands grafting to introduce desirable agronomic characteristics. However, the effect of grafting on the response of the crop to iron deficiency has not been well studied to date.

Therefore, we conducted a study to evaluate the tolerance of non-grafted quince seedlings and pear grafted onto quince to evaluate iron deficiency, depending on the application of a nutrient solution with chelated iron.

\section{Material and Methods}

The experiment was conducted under greenhouse conditions at the University of Cordoba, Spain, using grafted and non-grafted fruit seedlings.

Quince (Cydonia oblonga Mill) semi-woody rooted cuttings, cultivar BA29, and pear (Pyrus Communis L.), cultivar Ercolini, grafted onto quince cultivar BA29 (rootstock) were used in the experiment. Two types of nutrient solutions were used: one that contained iron ( $80 \mu \mathrm{M}$ Fe-EDDHA) and another one that did not contain iron. The treatments were arranged in the greenhouse according to a completely random design, with eight repetitions. The nutrient solution in both treatments had the following chemical composition: $2 \mathrm{mM} \mathrm{Ca}\left(\mathrm{NO}_{3}\right)_{2} ; 0.75 \mathrm{mM} \mathrm{K}_{2} \mathrm{SO}_{4}$; $0.65 \mathrm{mM} \mathrm{MgSO}_{4} ; 0.5 \mathrm{mM} \mathrm{KH}_{2} \mathrm{PO}_{4} ; 50 \mu \mathrm{M} \mathrm{KCl}, 10$ $\mu \mathrm{M} \mathrm{H}_{3} \mathrm{BO}_{3} ; 1 \mu \mathrm{M} \mathrm{MnSO}_{4} ; 0.5 \mu \mathrm{M} \mathrm{CuSO}_{4} ; 0.5 \mu \mathrm{M}$ $\mathrm{ZnSO}_{4}$; and $0.05 \mu \mathrm{M}\left(\mathrm{NH}_{4}\right)_{6} \mathrm{Mo}_{7} \mathrm{O}_{24}$.
The seedlings were transplanted on April $30^{\text {th }}$, 2010, in 3-L pots containing an alkaline soil plus sand (2:1). The experimental unit was formed by one pot containing one plant. On June $3^{\text {rd }}$, 2010, each pot received $250 \mathrm{~mL}$ of the nutrient solution.

The plant chlorophyll was indirectly measured during the experimental period using a portable SPAD-502 device (Minolta Camera CO, Ltd., Japan) in two young expanded leaves, with two readings per leaf. The stem length (starting from the budding point up to the petiole base of the last leaf) was also measured. These evaluations took place on June $1^{\text {st }}, 10^{\text {th }}$, $24^{\text {th }}$, and $30^{\text {th }}$ and on July $1^{\text {st }} 7^{\text {th }}$, and $15^{\text {th }}, 2010$.

At the last evaluation, the main stem that emerged after the start of the application of the treatments was collected, and its dry weight was also determined. In addition, recently expanded leaves were collected for chemical analysis to determine their total iron composition, according to the methodology described by Bataglia et al. (1983).

\section{Results and Discussion}

The presence of iron in the nutrient solution resulted in higher SPAD values for the non-grafted quince plants from the beginning of the experiment (Figure 1a), whereas, in pear, different SPAD values were observed only from the third week and thereafter (Figure 1b).

Thus, the results indicated that the pear plants exhibited a higher resistance to changes in the SPAD values when under stress conditions (soil with a low availability of iron) than the quince plants. When the plants grew in the ironless soil, the SPAD values of the quince leaves (7.3) at the end of the experiment were half the value of the pear plants (14.6) (Figure 1). Similar results were reported in the study of Dolcet-Sanjuan et al. (1992), in which pear plants (Pyrus amygdaliformis) showed a higher chlorophyll content than quince plants (Cydonia oblonga) under conditions of iron deficiency. 


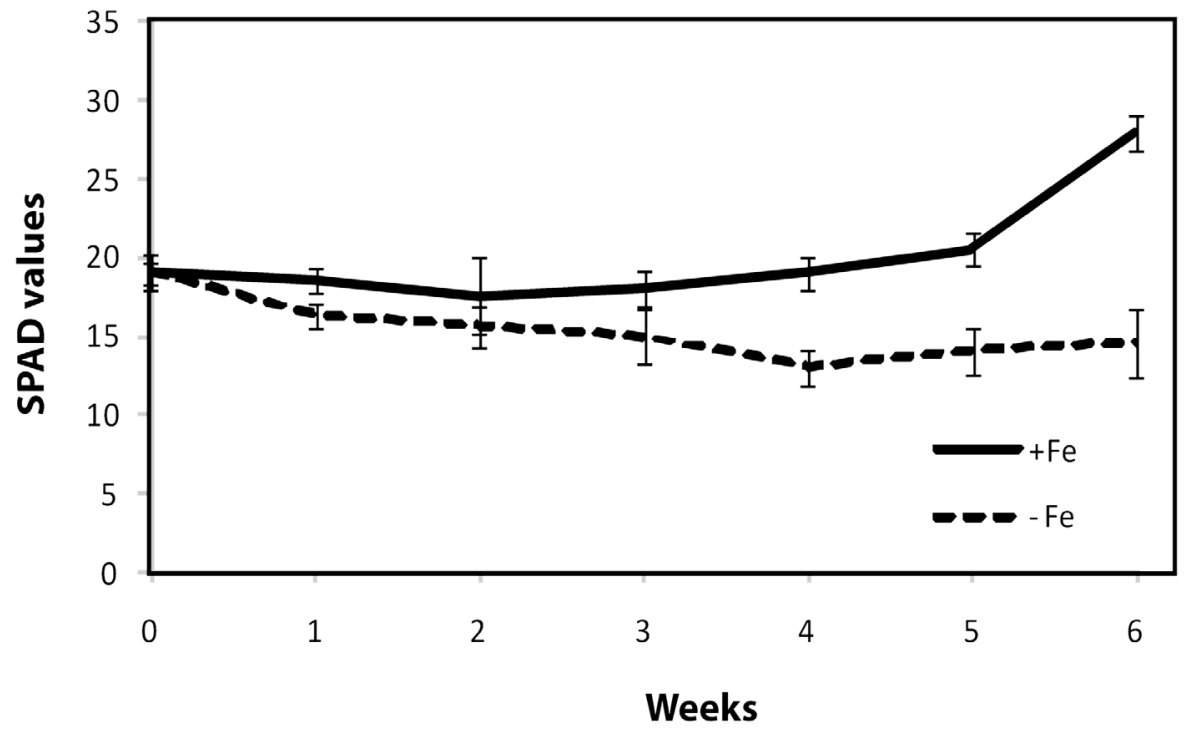

Figure 1. SPAD values in quince leaves (non-grafted) (a) and pear (grafted onto quince) (b) grown in an alkaline soil treated with iron-enriched $(+\mathrm{Fe})$ and ironless $(-\mathrm{Fe})$ nutrient solutions for 6 weeks.

The leaf iron content did not vary significantly between pear and quince plants when grown with a nutrient solution containing iron (Figure 2). Therefore, although they exhibited more chlorotic symptoms and lower SPAD values (Figure 1), the plants that had not been treated with iron had total iron contents that were similar to the plants that were treated with iron. This indicates that the evaluation for the total iron content in the plant could be influenced by iron precipitated in the leaf apoplast (Mengel and Geurtzen, 1988), which is physiologically irrelevant and capable of introducing errors in the nutritional evaluation. It is known that the total concentration of iron in the leaves is not a valid index of the plant nutritional status. Romheld (2000) has observed that the total iron concentration in chlorotic leaves is similar to that in green leaves. In the literature, it is reported that the best iron evaluation method is extraction with phenanthroline $(\mathrm{pH}$ 3) using fresh leaves rather than measuring the total content (Neaman and Aguirre, 2007). 


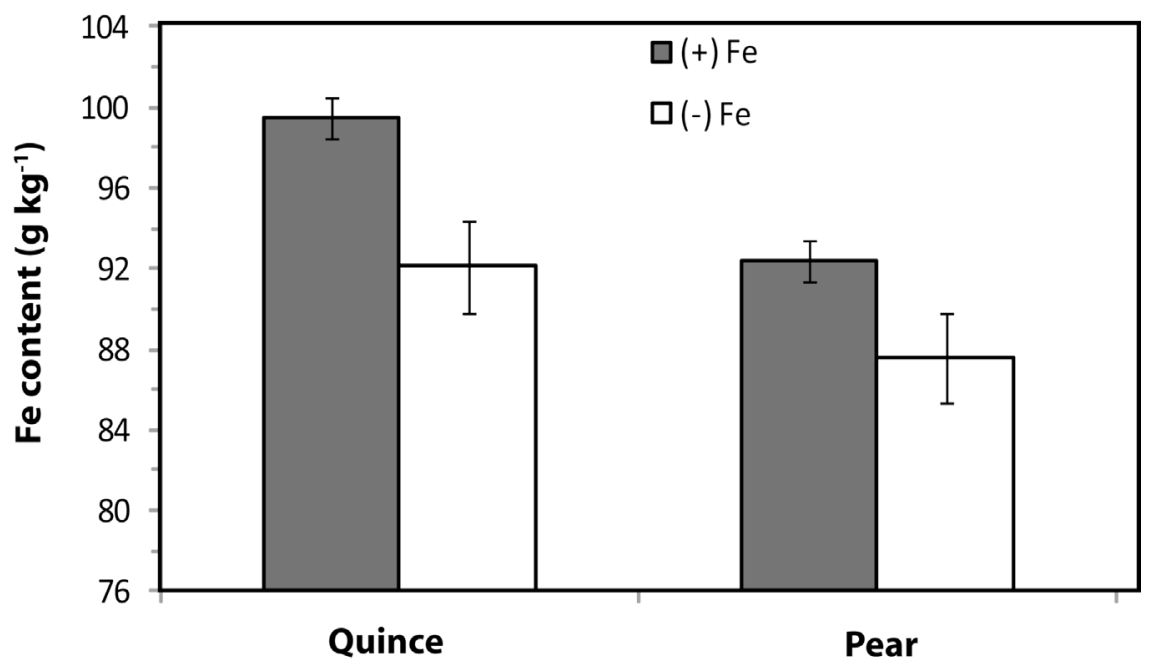

Figure 2. Foliar iron content of quince (non-grafted) and pear (grafted onto quince) grown in an alkaline soil, resulting from the presence of iron-enriched $(+\mathrm{Fe})$ and ironless $(-\mathrm{Fe})$ nutrient solutions in the sixth week of cultivation.

The highest stem length value of quince occurred in the plants treated with iron in the sixth week after the commencement of the treatments (Figure 2a). Thus, the iron deficiency (Figure 1a) effect on the quince stem length occurred slowly. The pear plants showed no stem length difference between the plants treated with and without iron. This lack of effect of iron application on the pear stem length might be due to the pear plants being more tolerant to iron chlorosis. This was also found in the assessment of the nutritional status using the indirect measurement of chlorophyll, as similar SPAD values between the treatments were observed until the third week of cultivation, as outlined above.
We found that iron deficiency is quickly reflected in low SPAD values but that its effect on stem length is slow. Studying pear plants of three genotypes cultivated in pots under low iron availability, Ma et al. (2005) reported similar results: low SPAD values but no significant differences in plant height.

When treated with iron, the quince stems had a higher dry matter weight than the plants that had not received iron (Figure 3a). The dry matter production of quince stems under iron application was higher than in the absence of the micronutrient (Figure 3a), a fact explained by the promotion of a higher photosynthetic rate, which was reflected in the higher SPAD value (Figure 1a) and the longest stem length in the sixth week after beginning the treatment (Figure 3a). 

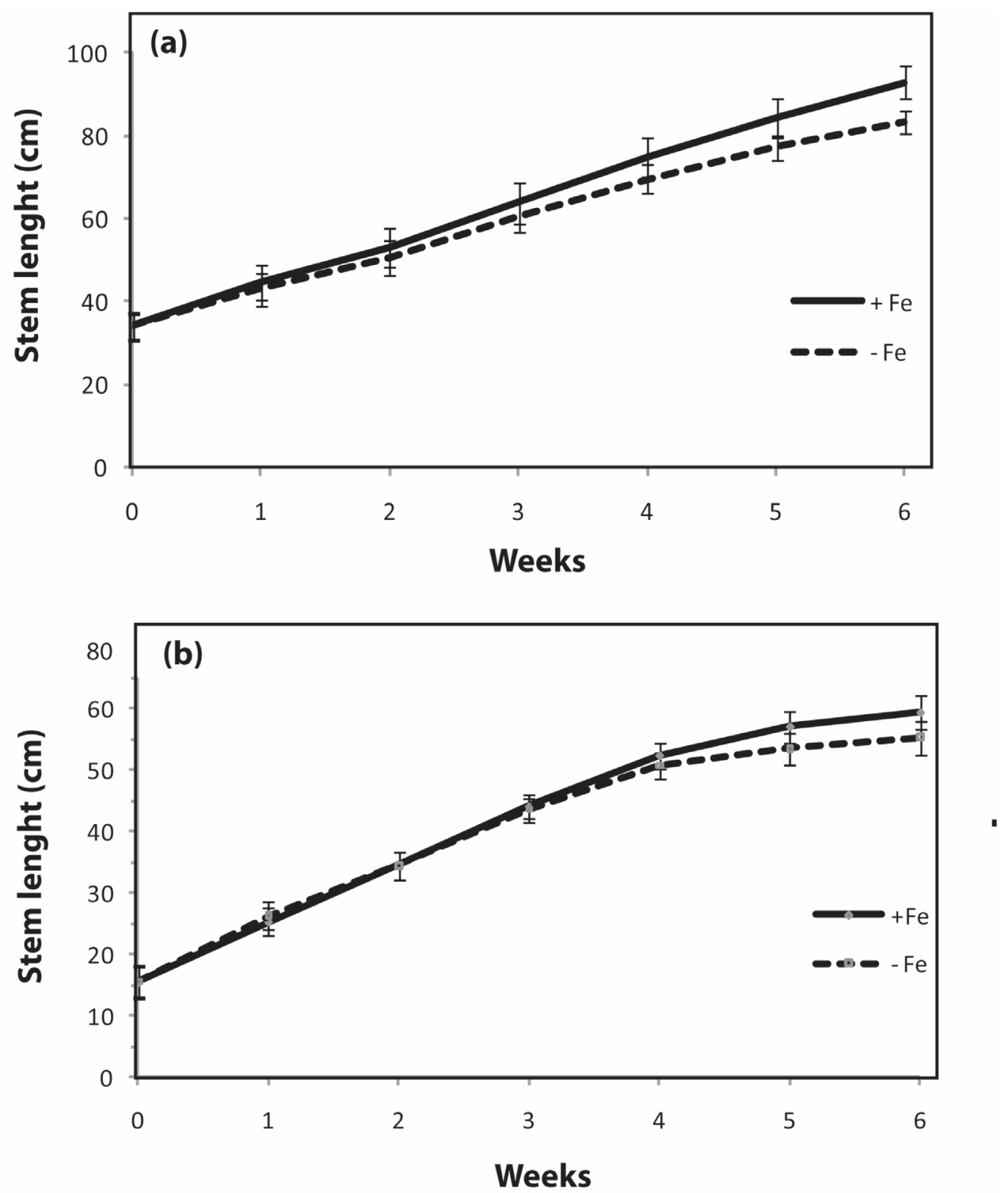

Figure 3. Quince stem length (non-grafted) (a) and pear (grafted onto quince) (b) grown in an alkaline soil, resulting from the presence of iron-enriched $(+\mathrm{Fe})$ and ironless $(-\mathrm{Fe})$ nutrient solutions in the sixth week of cultivation. 
The pear plants, however, showed no differences between the treated and untreated plants either for the branch dry matter weight (Figure $4 b$ ) or for the stem length (Figure $3 b$ ).

Therefore, a different tolerance to iron deficiency was noted for these genotypes. Similar re- sults were reported by Alcantara (2005) for olive, McDaniel and Brown (1982) for oats, Saxena and Sheldrake (1980) for chickpea, Zaiter et al. (1982) for beans, Samdur et al. (2000) for peanuts, and Ma et al. (2005) for pear.

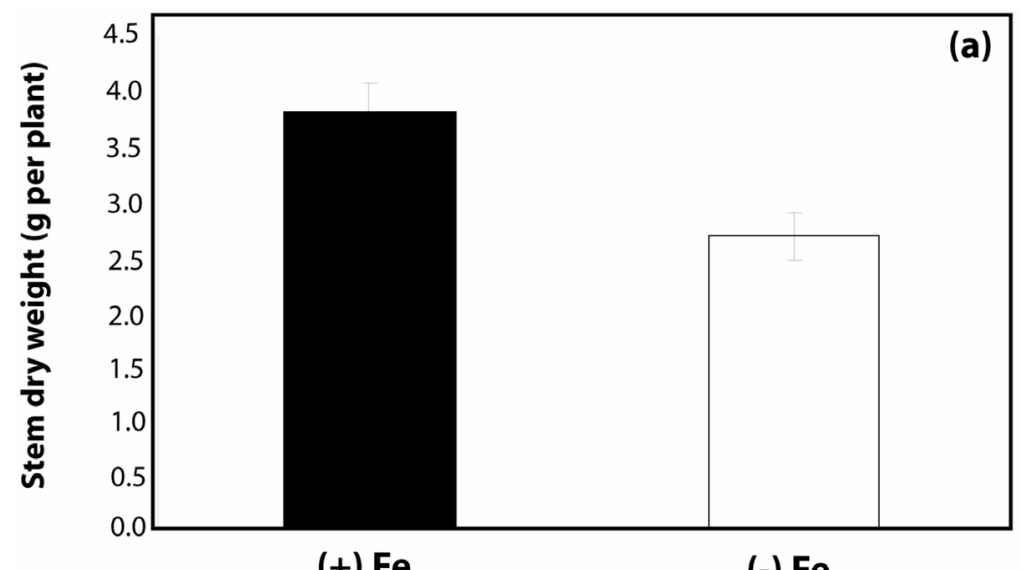

(+) Fe

(-) Fe

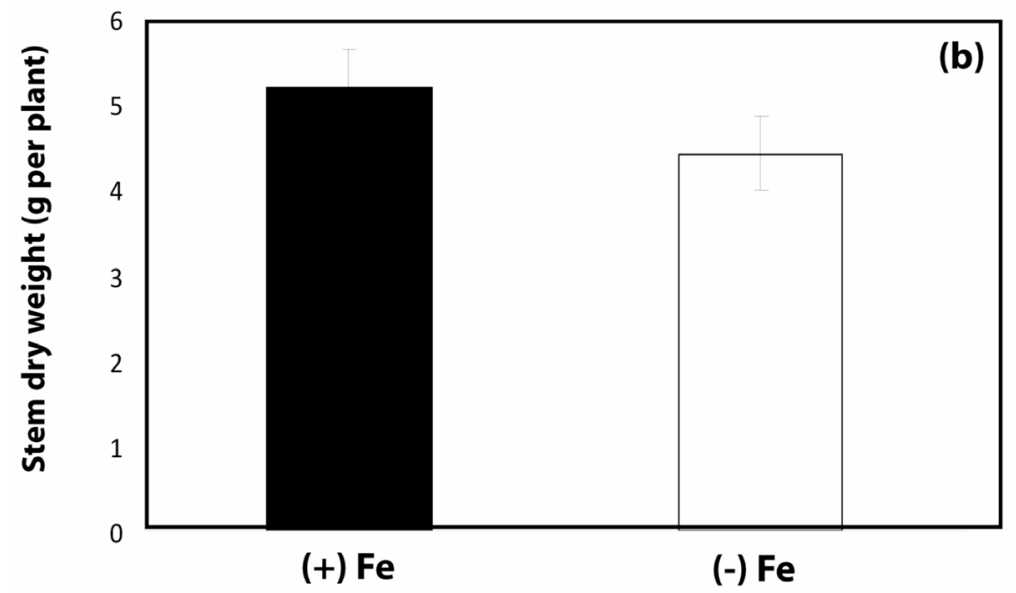

Figure 4. Quince stem dry weight (non-grafted) (a) and pear (grafted onto quince plants) (b) in an alkaline soil, resulting from the presence of iron-enriched $(+\mathrm{Fe})$ and ironless $(-\mathrm{Fe})$ nutrient solutions in the sixth week of cultivation. 
According to our results, the quince plants were susceptible to iron deficiency and may have a low ability for nutrient absorption from the soil at low concentrations. However, when grafted onto pear is grafted onto quince rootstock, the quince becomes more tolerant to iron chlorosis. Thus, it may be concluded that good tolerance to iron deficiency may be linked to biochemical and physiological processes after the absorption of the nutrient either because it is more extensively distributed or because of the efficiency in the use of the nutrient present in the aerial part of the plant, optimising metabolism and biomass conversion. In a tissue culture study, Dolcet-Sanjuan et al. (1992) evaluated the behaviour of Pyrus amygdaliformis and Cydonia oblonga with regard to tolerance to iron deficiency and observed that the former species is more tolerant due to its higher efficiency in reducing $\mathrm{Fe}^{+3}$ to $\mathrm{Fe}^{+2}$ and the acidity of the plant tissues. Some authors have suggested the usefulness of biochemical evaluations of the plant cells of select fruit genotypes tolerant to iron chlorosis, including the reductase activity (Ma et al., 2006) and H-ATPase (Donnini et al., 2009), enzymes that are linked to iron absorption by strategy I. This strategy is characterized by the enhance of the ferric reductase capacity located at the root surface.

Although quince has been used essentially as the preferential rootstock for pear plants, being plants of short stature that bear fruit early (Nogueira, 1985), further research is important for the selection of cultivars that are tolerant to iron deficiency, as it is a plant susceptible to iron chlorosis.

\section{Conclusions}

The use of grafting in pear seedlings using quince plants as the rootstock induced a higher tolerance to iron deficiency than in the non-grafted quince plants.
Compared with the application of iron in the nutrient solution, non-grafted quince plants growing without added iron showed low SPAD values and led to a reduced leaf iron content and lower dry matter production; however, reduced seedling stem growth was observed only in the last week of cultivation.

\section{References}

Alcantara, E. Tolerancia y sensibilidad a la clorosis férrica. 2005. In: Variedades de olivo en Espana. Rallo, D.B.; Caballero, J.M.; Del Rio, C.; Martin, A.; Tous, J.; Trujillo, I. (Eds.). Madri: Junta de Andalúcia, MAPA, Multi-Prensa,315-319.

Bataglia, O. C., Furlani, A.M.C., Teixeira, J. P. F., Furlani, P. R., Gallo, J. R. 1983. Métodos de análise química de plantas. Campinas, Instituto Agronômico, 48p. (Boletim técnico, 78).

Chaney, R.L. 1984. Diagnostic practices to identific iron deficiency in higher plants. Journal Plant Nutrition, 7, 47-67.

Cinelli, F., Loreti, F.; Muleo, R. 2004. Regeneration and selection of quince BA29 (Cydonia oblonga mill.) somaclones tolerant to lime-induced chlorosis. Acta Horticulturae, 658, 573-579

Dolcet-Sanjuan, R., Mok, D.W.S., Mok, M.C. 1992. Characterization and in vitro selection for iron efficiency in Pyrus and Cydonia. In Vitro Cellular \& Developmental Biology - Plant. 28, 25-29

Donnini, S., Castagna, A., Ranieri, A., Zocchi, G. 2009. Differential responses in pear and quince genotypes induced by Fe deficiency and bicarbonate. Journal of Plant Physiology. 166, 11811193.

El-Kassas, S.E. 1984. Effect of iron nutrition on the growth, yield, fruit quality, and leaf composition of ceded balady lime trees grown on sandy calcareous soils. Journal of Plant Nutrition. 7, 301-311. 
Fernández Escobar, R., Barranco, D., Benlloch, M. 1993. Overcoming iron chlorosis in oliver and peach trees using a low-pressoure trunk injection method. HortScience, 28, 192-194.

Herrero, J., Abadía Conte, A. 1962. Comportamiento de arboles frutales en suelos calizos. An. Aula Dei. 7, 35-55.

Lindsay, W.L. 1995. Chemical reactions in soils that affect iron availability to plants. A quantitative approach. In: Iron Nutrition in soils and plants,p.7-14. Ed. J. Abadia. Kluwer Academic Publishers.

Ma, C., Tanabe, K., Itai, A., Tamura, F., Chun, J., Teng, Y. 2005. Tolerance to lime-induced iron chlorosis of Asian Pear rootstocks (Pyrus spp.). Journal Japan Sociedad Horticulturae Science. 74, 419-423.

Ma, C., Tanabe, K., Itai, A., Tamura, F., Teng, Y., Chun, J. 2006. Response of two Asian Pear rootstocks (Pyrus spp.) to Fe-deficiency chlorosis induced by addition of bicarbonate to nutrient solution. Journal Japan Sociedad Horticulturae Science. $75,219-223$.

MAPA. Ministerio de Agricultura, Pesca y Alimentacion.2007. Disponível: www.mapa.es

Mcdaniel, M.E., Brown, J.C. 1982. Differential iron chlorosis of oat cultivars - a review. Journal of Plant Nutrition, 5, 545-552

Mengel, K.., Geurtzen, G. 1988. Relationship between iron chlorosis and alkalinity in Zea mays. Physiologia Plantarum. 72, 460-465.

Mengel, K., Breininger, M.T., Bubl, W. 1984. Bicarbonate, the most important factor inducing iron clorosis in vine grapes on calcareous soil. Plant and Soil. 81, 333-334.
Neaman, A., Aguirre, J. 2007. Comparison of different methods for diagnosis of iron deficiency in avocado. Journal of Plant Nutrition. 30, 1097-1108.

Nogueira, D.J.P. 1985. Os porta-enxertos na fruticultura de clima temperado. Informe Agropecuário. 11, 3-12.

Nunes, F.N., Novais, R.F., Silva, I.R., Gebrim, F.O., São José, J.F.B. 2004. Diffusive flux of iron in soils influenced by phosphorus rates and levels of acidity and moisture, Revista Brasileira de Ciência do Solo, 28,423-429.

Prado, R.M.2008. Nutrição de plantas. São Paulo: Unesp, 407p.

Romheld, V. 2000. The chlorosis paradox: Fe inactivation as a secondary event in chlorotic leaves of grapevine. Journal of Plant Nutrition. 23, 16291643.

Samdur, M.Y., Singh, A.L., Mathur, R.K., Manivel, P., Chikani, B.M., Gor And, H.K., Khan, M.A. 2000. Field evaluation of chlorophyll meter for screening groundnut (Arachis hypogaea L.) genotypes tolerant to iron-deficiency chlorosis. Current Science. $79,221-230$.

Sanz, M., Pascual, J., Machín, J. 1997b. Prognosis and correction of iron chlorosis in peach trees: influence on fruit quality. Journal of Plant Nutrition. 20, 1567-1572.

Sanz, M., R. Belkhodja, M. Toselli, L. Montañés, A. Abadía, M. Tagliavini, B. Marangoni, J. Abadía. 1997a. Floral analysis as a possible tool for prognosis of iron deficiency in peach. Acta Horticulturae. $448,241-245$.

Stein, A.J. Global impacts of human mineral malnutrition. Plant and Soil, 335,133-154,2010. 
Saxena, N.P.; Sheldrake, A.R. 1980. Iron chlorosis in chickpea (Cicer arietinum L.) grown on high $\mathrm{pH}$ calcareous vertisol. Field Crops Research. 3,211214.

Tagliavini, M., Abadía, J., Rombolà, A.D., Abadía, A., Tsipouridis, C., Marangoni, B. 2000. Agronomic means for the control of iron chlorosis in deciduous fruit trees. Journal of Plant Nutrition. 23, 2007-2022.

Tagliavini, M., Rombola, A.D., Marangoni, B. 1995. Response to iron-deficiency stress of pear and quince genotypes. Journal Plant Nutrition. 18, 2465-2482.

Zaiter, H.Z., Coyne, D.P., Clark, R.B. 1982. Genetic variation and inheritance of resistance of leaf iron-deficiency chlorosis in dry beans. Journal of the American Society for Horticultural Science. 112, 1019-1022. 